DOI: $10.2478 / \mathrm{v} 10122-011-0011-8$

\title{
THE CASE OF INTERACTIVE METAPHOR ${ }^{1}$
}

\author{
ALEKSANDER KIKLEWICZ
}

Abstract: Aleksander Kiklewicz. The Case of Interactive Metaphor. Lingua Posnaniensis, vol. LIII (2)/2011. The Poznan Society for the Advancement of the Arts and Sciences. PL ISSN 0079-4740, ISBN 978-83-7654-173-0, pp. 35-47.

The author analyses the limits of metamorphosis, i.e. possibility of an utterance with idiomatic or nonconventional, disturbing selection requirements of syntagmatic components being considered as metaphorical. The phenomena of metaphor and metonymy are interpreted from the point of view of condensation of surface structure of a sentence, as well as from the point of view of intentional semantics. The author presents elements of metaphor theory as a pragmatic re-codification, treating metaphor as a kind of "multi-vocality" or an intertext.

Aleksander Kiklewicz, University of Warmia and Mazury, Olsztyn

\section{METAPHOR AS A PRAGMATIC TRANSCODING}

Metaphorical expressions, examined outside the communication context, are marked for their non-completeness, similarly to all condensed expressions, which was pointed out by Stanisław Karolak who says:

An expression put into the empty position in the semantic structure, and being an element of the syntagma, obviously represents the complete syntagma, not just a missing linguistic element. To illustrate, in the utterance he was paying in silver the position of the nominal group was filled that signifies some object. The position is empty, as a result the meaning is underdetermined, namely 'he was paying in something which stayed in some relation to silver'. A more detailed meaning, which a listener may impose upon such an utterance, depends on the interpretation of this utterance (in an extended cultural-cognitive context - addition mine - A.K.), and not on its semantic features (KAROLAK 1999: 364; English translation).

Correspondingly, metaphorical expressions are underdetermined from the structurallinguistic point of view; they only point to a similarity or association between the designates. Hence, effective functioning of a metaphor in linguistic communication is possible only while taking into account the context - textual, situational, cultural, etc. The context allows for a proper interpretation of metaphorical expressions, that is, the interpretation adequate with reference to the sender's intention. Andrzej Bogusławski writes that metaphorical expressions are 'logically not essential as far as the so-called natural language is regarded [...]. They are built on the basis of other interpretations in the context of a given language exchange situation' (BogusŁAWSKI 1994: 138; English translation). An illustration taken from the press article:

1 Translated by Marta Bogusławska-Tafelska. 
(1) Aleksander Kwaśniewski nazwał Polskę Chinami Europy. Ani chybi będzie opozycję zamykał albo i ryż sadził. [...] Podczas otwarcia forum gospodarczego prezydent nazwał Polskę „małymi Chinami Europy", co wywołało lekkie uśmieszki na ustach zgromadzonych, a niektórzy komentatorzy pytali później, czy chodzi o bezrobocie ("Wprost"; 2004/20).

Translation: Aleksander Kwaśniewski labeled Poland as the China of Europe. Without fail, he will be getting the opposition behind bars, and, probably, cropping rice. [...] During the opening meeting of the economic forum, the President 'labeled Poland as the miniature China of Europe', which evoked sneers on the faces of the public; later, some commentators were asking whether he meant unemployment.

One can notice that the metaphor Poland is the miniature China of Europe is open for various semantic interpretations (President is said to mean Poland being a dynamically developing country, cooperating with the economic world), which is the consequence of the status of metaphorical expressions, in particular, occasional ones, that is, metaphors created on special occasions. Putting the social-cultural context aside, Kwaśniewski’s metaphor literally means: 'Poland is a small country in Europe, similar to China with reference to particular features; I assume that you know which features I mean'.

The underdetermined nature of metaphor causes its functional-pragmatic treatment in contemporary linguistic research: metaphor is considered in the context of its specific cultural convention, between the sender and the receiver; the convention allows for the complementation of the semantic content of metaphorical expressions (see also: KIKLEWICZ 2009a: 57; 2009b: 178). Searle was realizing this postulate:

The metaphorical utterance is that a speaker utters a sentence of the form $S$ is $P$ and means metaphorically that $S$ is $R[\ldots]$ In the case of literal utterance, speaker's meaning and sentence meaning are the same; therefore the assertion made about the object referred to will be true if and only if it satisfies the truth conditions determined by the meaning of the general term as applied against a set of shared background assumptions. In order to understand the utterance, the hearer does not require any extra knowledge beyond his knowledge of the rules of language, his awareness of the conditions of utterance, and a set of shared background assumptions. But, in the case of the metaphorical utterance, the truth conditions of the assertion are not determined by the truth conditions of the sentence and its general term. In order to understand the metaphorical utterance, the hearer requires something more than his knowledge of the language, his awareness of the conditions of the utterance, and background assumptions that he shares with the speaker. He must have some combination of principles and information that enables him to figure out that when the speaker says, $S$ is $P$, he means $S$ is $R$ (SeArle 1979: 98-99; see also: SpagińsKa-PruszaK 2005: 191).

The functional-pragmatic approach to metaphor consists in accepting the communicational context of the utterance, that is, the different viewpoints realized in its semantic content. So, according to Searle's assumption, metaphorical expressions contain 'sentence meaning' complemented by occasional meaning, initiated by the sender, which is 'a speaker's meaning'. As an up-to-date, communicationally relevant meaning of metaphorical expressions - non-conventional, 'living' as they are - is not to be reduced to the meanings of the lexical components, it is open to diverse interpretations conditioned by the situational context; in consequence, metaphors, or at least some type of metaphors, cannot be regarded as a phenomenon of the system of language. On the one hand, as SEARLE observes, interpretation of metaphorical expressions requires a perceptual base common to the interlocutors. It requires a shared communicational strategy that would allow for identification of the linguistic behavior as non-conventional; or specification of the subcategory of derivative meanings of metaphorical expressions (1979: 120).

In its strong version, the communicative theory of interactional metaphor takes shape as the theory of the pragmatic transcoding. This standpoint is presented in my earlier 
work (see: KIKLEWICZ 2009a). In this approach, metaphor is described as a phenomenon integrated with the communicative sphere, namely, with the existence of numerous areas, styles, 'voices', etc. An utterance taken from a public speech may serve as an example:

(2) Za dużo jest wentyli do wypuszczania swoich żalów („Polityka”; 1989/21).

Translation: There are too many valves to let out one's hard feelings.

This sentence means: 'A person who too often and too intensively expresses his/her hard feelings, a person who is sorrow-driven and led by feelings of resentment'. The nominal group valves to let out was used in the metaphorical sense: the ability to express, the ability to act while driven by..., etc. Apart from the semantic pluralism (the polysemy of the noun valve) one can notice here pragmatic pluralism: the phrase valve to let out comes from the professional (or technical) language, and contrasts with the rest of the co-text being in the colloquial/neutral convention. Here the metaphor can be interpreted as a type of borrowing of elements from a different functional style. While taking into consideration the communicative aspect of metaphorisation, the utterance (2) can be analyzed in the following way:

'A person with technical educational background could say that there are too many valves to let out one's hard-feelings'.

So, one can notice here a metaphorical text encapsulating in its semantic structure a reference to another, alternative subject and another alternative language or rather sublanguage, 'a foreign word' in Mikhail BACHTIN's terminology (1979: 269). A particular polyphony is present in the metaphor.

Voice A: The topic includes expressing one's hard feelings.

Voice B: The topic includes use of the valves.

The polyphony can be traced in texts which simultaneously contain two types of nomination - primary, involving the perspective of the real sender; and the metaphorical one, that is the one involving the perspective of the virtual voice. The illustration comes from the article of Juliusz Mieroszewski (see: DE LAZARI 2007):

(3) Nie możemy stać na stanowisku, że każdy program wielkorosyjski jest imperializmem - natomiast polski program wschodni nie jest żadnym imperializmem, tylko wzniosłą „i deą ja gi e 1lońs ką" [...] „Id e a jagi ellońs k a” tylko dla nas nie ma nic wspólnego z imperializmem, jednak dla Litwinów, Ukraińców i Białorusinów stanowi najczystszą formę polskiego tradycyjnego i mpe ria lizm u .

Translation: We cannot claim that every Great-Russian program is an instance of imperialism, while the Polish eastern program is no imperialism, it is a noble 'Jagiellonian idea' [...]. 'The Jagiellonian idea' has nothing to do with imperialism only from our perspective; however, for Lithuanian, Ukrainian or Belarusian people it remains a pure traditionally Polish type of imperialism.

In this excerpt, the nominal group the Jagiellonian idea - in the author's view - is synonymous with the primary nomination form - the noun 'imperialism', while one can also notice a clear co-occurrence of two viewpoints: a neutral viewpoint ('Polish eastern policy is a form of imperialism'), and a Polish viewpoint ('Polish eastern policy is based on the Jagiellonian idea').

Furthermore, metaphor presupposes a differentiation of the cultural sphere, and, as a consequence, a differentiation of the communication sphere. As it constitutes an example of appealing to 'a foreign voice', a similarity between metaphor and citation becomes more than just a coincidence. The inverted commas are the formal marker of this resemblance - a graphic sign which marks not only the quoted sentences/texts, but also ex- 
pressions used metaphorically or ironically. A difference is that in the case of a citation there the objective is to preserve the exact, original content; semantic deviations are rare, unintentional, being the effect of interaction between 'the foreign word' and new context (Valentin N. VološINOV wrote about this dynamic functioning of 'the foreign word', 1995: 335). In the case of metaphorisation, conversely, the aim of the subject is to adjust the sign to the new content, and the 'old' content is visible in the form of the connotation, i.e. the additional meaning. A particular semantic double perspective of metaphorical expressions is created, along with the expressiveness of the metaphorical way of nomination. As an example, one can cite a fragment of a press article, in which expressions such as zgnite owoce 'the fruit of the poisonous' tree are used both in the primary and the metaphorical sense:

(4) Nie obowiązuje [...] w Polsce zasada „zgniłych owoców”, znana choćby w USA, zgodnie z którą nie można wykorzystać dowodów uzyskanych wbrew prawu. W Polsce zgniłe ow oce można je ść - powiedział sędzia Sobczak („Rzeczpospolita”; 16 XII 2004).

Translation: In Poland 'the fruit of the poisonous tree' doctrine is not working like, say, in the US, according to which evidence obtained as a result of illegal actions cannot be made use of. In Poland, the fruit of the poisonous tree may be eaten — said judge Sobczak.

Metaphorical expressions put in inverted commas constitute a typical feature of quality press publications - in this way, they create the semantic multidimensionality of the press text. Further examples come from excerpts from Anna Łabuszewska's articles published in 'Tygodnik Powszechny' (17 and 24 VIII 2008) entitled Czy Gdańsk leży dziś na Kaukazie? (Is Gdansk sited in the Caucasus today?) and Sezon na jastrzebie (The season of hawks):

(5) Narzędziem obrony rosyjskich interesów na Kaukazie jest armia, która „w celach humanitarn y c h" bombarduje Gruzję mimo apeli strony gruzińskiej o zawieszenie broni i negocjację.

Translation: The army, being a Russian tool of influence exertion in the Caukasus, 'in a humanitarian intervention' is bombing Georgia, in spite of the appeals for ceasefire and negotiations on the part of the Georgians.

(6) Gruzja dopuściła się agresji na terytorium chronione przez „siły ro zje m c ze” (tj. rosyjskie).

Translation: Georgia committed an act of military aggression against the region protected by 'the truce forces' (that is, Russian truce forces).

(7) Miedwiediew pojawił się na scenie 12 sierpnia, by rzucić hasło wstrzymania działań bojowych (przepraszam: „operacji pokojowej”).

Translation: Medvedev entered the scene on 12 August to announce the end of military operation (pardon: 'the peacekeeping operation').

(8) Putin wykonał robotę ,j a s trzę bi i".

Translation: Putin did 'the hawk's' job.

(9) Wątpliwości co do charakteru obecności Rosji w regionie rozwiało też wprowadzenie kontyngentu wojskowego [...] do Abchazji, gdzie otwarto „drugi front”.

Translation: The entry of the military contingent in Abkhazia dispelled the doubts regarding the character of the Russian presence (..); in Abkhazia 'the second front' was opened.

(10) Reakcje społeczności międzynarodowej są na razie miękkie. Nic nie wskazuje na to, że obywatele wolnego świata zechcą umierać za „k a u k s ki Gdańsk”.

Translation: The reactions of the international community are mild for the time being. Nothing suggests that the citizens of the free world are willing to die for 'the Caucasian Gdansk'.

In expressions of this type, one can notice examples of the speech which is only quasi direct: regardless of the fact that the subject of the foreign nomination is not explicitly present, the cultural context clearly points to him/her. For example, in sentences (5)-(7) 
the author is not straightforward in her references to Russian politicians' standpoints, who present the military aggression in Georgia as a humanitarian or peace action undertaken by the truce forces. In sentences (8)-(10) the phrases: the hawk, the second front, the Caucasian Gdansk, can be ascribed to a hypothetical sender ('One could say...'), who may be either an observer of a predator's behavior in wild nature in sentence (8), or an observer of Second World War events in sentence (9), or an observer of the Poland of 1938-1939 in sentence (10). It has to be noted here that the author, in a sense, identifies herself with this virtual observer-interpreter.

\section{METAPHOR IN SEMASIOLOGICAL APPROACH}

From the semasiological perspective, based on the methodology 'from the form to the content', metaphor constitutes a type of polysemy (with multiple meanings). In this sense, the dispersive character of the semantic function of a sign becomes central, which is a feature that can be discussed from the communicational point of view; this feature can be regarded as a consequence of using a sign by different subjects, in different types of discourse. It may be presented schematically as follows:

\begin{tabular}{|l|l|l|}
\hline \multirow{4}{*}{ FORM } & CONTENT & SUBJECT \\
\cline { 2 - 3 } & Content $_{1}$ & Subject $_{1}$ \\
\hline Content $_{2}$ & Subject $_{2}$ \\
\hline Content $_{3}$ & Subject $_{3}$ \\
\hline
\end{tabular}

I will illustrate the application of this model with the following example:

(11) W hotelu „Białoruś” na każdym piętrze jest „etażnaja”, która kontroluje klucze, a wokół stolika, gdzie piliśmy kawę, krążyło, nie ukrywając ciekawości, dwóch smutnych „,tu ry s tó w” („Gazeta Wyborcza”; 27 VI 2006).

Translation: In the hotel 'Belarus' on each floor there is 'etaznaja' - a person in charge of the keys - and around the table, where we were drinking coffee, two sad 'tourists' were wandering with curiosity that they did not hide.

The noun in inverted commas - 'tourist' - was used metaphorically here: the author consciously and ironically labels the Belarusian communist secret service agents as tourists:

\begin{tabular}{|c|c|c|}
\hline \multirow{3}{*}{$\begin{array}{l}\text { FORM } \\
\text { tourist }\end{array}$} & CONTENT & SUBJECT \\
\hline & $\begin{array}{l}\text { Content }_{1} \\
\text { A person who travels and stays outside his/her place of } \\
\text { living to do some recreation or exploration }\end{array}$ & Subject $_{1}$ \\
\hline & The agent of the Belarusian communist secret service & Subject $_{2}$ \\
\hline
\end{tabular}

The semasiological model encapsulates only the fact of one and the same form being used in different communicative situations by different subjects and realizing different meanings; whether this polysemy of the form is an element of the linguistic consciousness of the subject remains unspecified. In other words, polysemy becomes here only an element of the system of language, not a cognitive, competence-marking phenomenon. This compi- 
lational, or cumulative approach to metaphor is popular in the lexicographic tradition, which is based on collecting several or sometimes a larger number of distinct semantic realizations of the same lexeme in different texts, often nonuniform stylistically. For example, the PWN CD-ROM dictionary gives five meanings of the Polish noun kęs (a bite):

kawałek czegoś jadalnego (a piece of something eatable);

rzadk. kawałek, część, pewna ilość czegoś, trochę, nieco (quant. piece, part, amount of something, bit);

górn. kęsy 'sortyment węgla o wymiarach ziaren ponad $125 \mathrm{~mm}$; sortyment koksu o wymiarach ziaren ponad 80 mm' (mining; bean coal 'a type of coal bean, the parameters of which extend 125 millimeters; a type of coke, the parameters of which extend 80 millimeters');

hutn. 'półwyrób stalowy o kształcie podłużnym i przekroju poprzecznym kwadratowym, prostokątnym, lub okrągłym, otrzymany przez kucie, wyciskanie lub walcowanie kęsiska lub wlewka (metallurgy; 'semi-product made of steel; longitudinal in shape; square, rectangular or round cross section; obtained in the process of forging, milling or rolling of metal);

łow. kęsy 'zęby zwierząt drapieżnych' (hunting; teeth of predators);

It is evident that divergent meanings operate in different spheres of language functioning, there being no interaction between them or no awareness of polysemy on the part of carriers of language.

One can notice that the semasiological model, especially its lexicographic version, generally accounts for the multisubject nature of metaphor, however, it can be applied to conventional, 'dead' metaphors, which means that they only convey the possible usages of the sign code (a set of the secondary nominations); the model does not reflect the actual processing of metaphors in the linguistic awareness nor their functioning in communication.

As a case of language nomination, namely, the secondary nomination, metaphor resembles the postmodernist text, which, in turn, can be compared to a palimpsest: it is as if being written on top of an old, worn out text written earlier. In a postmodernist text, as in palimpsests, the old text sometimes comes out from below the secondary layer. It means that it is not only the primary, asserting aspect or motif of the utterance which undergoes semantic processing, but also various accompanying aspects: presuppositions, connotations, the surface form, the primary meaning, etc. A metaphor has a similar structure: every novel meaning can be treated as a particular novel text written by the next author on top of the old text and, thus, constituting a new layer on the same language form. Occasionally, the primary semantic content may appear in the structure of the utterance, as a result a phenomenon of equivocation or parasemy comes into being (see also: KIKLEWICZ 2006: 6). The examples are linguistic utterances like (4), which realize the semantic twofold construction.

\section{METAPHOR IN THE ONOMASIOLOGICAL APPROACH}

The semasiological model does not resolve a problem of the unconventional metaphor based on the interaction of meanings, which was brought up by Ivor Armstrong RicHARDS (1936). A multiplicity of meanings does not necessarily equate pragmatic transcoding. Discourse as a linguistic activeness of the subject creates an arena on which the interaction of meanings or voices takes place; interacting voices are authors of the primary or secondary nomination. Stephen ULLMANN, whose statement agrees with such an approach to metaphor, commented on the pathological nature of metaphor - and polysemy in general - employing medical terminology: in polysemy we can notice pathology when two or more opposing 
meanings, which gather around one and the same name/language form, in the same context would have the same sense (1967: 114). The non-conventional metaphor, the one which is 'alive' and interactive, is founded on the basic fact of the language subject being fully aware of the polysemy, that is, of his/her access to the voice interaction. The onomasiological model of metaphor allows for such a view on metaphor in which the direction of the scientific analysis is 'from the content to the form'; in such cases, metaphor is regarded as an alternative nomination, conditioned by the involvement of 'the other' in the discourse, according to the rule: 'somebody / a foreigner would say that...'

\begin{tabular}{|c|c|c|}
\hline $\begin{array}{c}\text { SUBJECT }_{1} \\
(\text { REAL })\end{array}$ & Content $_{1}$ & \\
\hline $\begin{array}{c}\text { SUBJECT }_{2} \\
(\text { VIRTUAL) }\end{array}$ & Content $_{2}$ & FORM $_{2}$ \\
\hline
\end{tabular}

This model reflects not only the polysemous character of the secondarily used sign

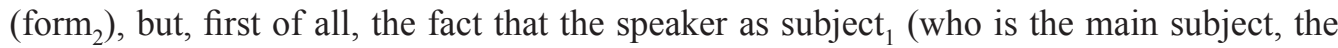
real subject - see below) remains in charge of the secondary nomination and the underlying meaning interaction, that is, the interpretation of content ${ }_{1}$ from the perspective of content ${ }_{2}$. To illustrate, in the sentence (7) the journalist as the actual subject uses the phrase operacja pokojowa 'the peacekeeping operation' in the secondary sense of 'military operation', indirectly referring to the virtual subject, that is, to pro-government Russian politicians and Russian media; it has to be noted that the subject associates this form with both types of content: the conventional and 'the foreign', adopted from the foreign cultural code - the inverted commas points to this, as in the examples below:

Voice A (actual): The Russian army was carrying out a military operation.

Voice B (virtual): The Russian army was carrying out a peacekeeping operation.

The implementation of unconventional metaphor causes a type of dissociation in the interaction: on the one hand, the real sender passes some message to a real receiver (about Russian aggression in Georgia); simultaneously, the real sender evokes the virtual sender's voice, who uses an alternative interpretation of the same fact, together with the alternative nomination. The following graphic representation illustrates the process and the alternative nomination ( $\mathrm{A}$ - marks communicating the information; $\mathrm{B}$ - marks the borrowing of the nomination form):

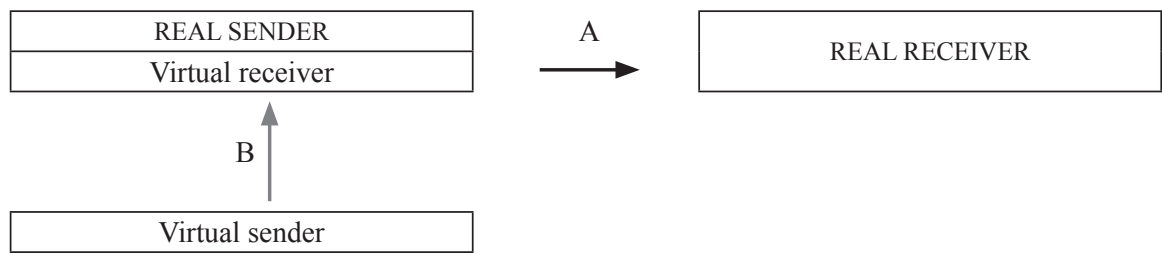

4. METAPHOR AS INTERACTION OF VOICES

In section 3, the virtual sender was treated as 'the foreign' or 'the other', in relation to the real sender. In fact, the interactional metaphor is not as much about evoking the voice of 'the other' in relation to the sender, as about evoking the voice of 'the other' in relation 
to the dominating semantic convention. Consequently, the voice of the sender may also be, theoretically speaking, distinct from the one adopted in the standpoint adopted in the narration (which can be described as generally accepted, traditional, etc.).

I propose the model of pragmatic transcoding, in which three different communicative subjects are singled out:

1. the transcultural subject - general or nonspecified: 'People say...' or 'One says...';

2. the endocultural subject: 'I say...' or 'Our people say...'

3. the exocultural subject: 'The foreign voice says...'

This classification is based on BACHTIN's triad: 'neutral word' - 'my word' - 'the foreign word' (1979: 269). This eminent Russian philologist and semiotician differentiated between three categories of cultural or 'ideological' marking in language in social communication. First, there is a general language or the 'neutral word', the function of which is to enable and realize communication and social integration. Second, within a culture one can observe a differentiation of language founded on the social structure; consequently, language variants come into being which are habitually or functionally marked (group or individual). This category was labeled by Bachtin as 'my word'; these are language signs used within the sphere of an individual's or a group's activity; the subject of communication remains within this sphere.

Third, communication subjects are aware of the existence of the 'foreign word', which is the property of diverse, alternative cultural formations, or other people representing different ideology and different expression. Bachtin was stressing the fact of the language activity and language competence development being predetermined by the opposition: 'my word' vs. 'foreign word':

Our language, comprising all our utterances, works of art included, is rich in foreign words, in different degree of foreignness or accommodation. Foreign words bring a certain expression, an evaluative tone, which gets processed and re-stressed by us (BACHTIN 1979: 269; English translation).

Three types of voice within the discourse structure can be configured in three ways, depending on which of the subjects, as a virtual subject evoked by the speaker, determines the metaphorical nomination. One can tabulate in the following way:

\begin{tabular}{|l|c|c|c|}
\hline \multicolumn{1}{|c|}{ SUBJECT } & I & II & III \\
\hline They say; somebody would say & $\times$ & & \\
\hline I say our people say & & $\times$ & \\
\hline The foreign voice says & & & $\times$ \\
\hline
\end{tabular}

At this point, I will characterize briefly each type of the metaphorical expressions.

Type I: the speaker is referring to an operating convention, with which he/she rather disagrees (or disagrees totally), or towards which he/she remains neutral.

Type II: the sender's voice is dominating, which refers to himself/herself, or to somebody that he/she perceives to be an expert in a certain area; the sender expresses his/her own point of view, or the point of view agreed upon, which remains in opposition to the standpoint of the majority.

Type III: the foreign voice is speaking, which means that the metaphor is based on foreign nomination and foreign designate interpretation; the sender not only distances himself from this nomination, but also sees it as contradictory with the present state of affairs. 
In this context, one consider a press note written by Adam Wajrak, in which 'the metaphor of an elk' created by Jarosław Kaczyński is commented upon:

(12) Panie Premierze, przeczytałem wywiad z Panem w „Rzeczpospolitej” i mnie zmroziło [...] Gdy przeczytałem, że „pchanie Polski do przodu” kojarzy się Panu z ,wyciąganiem łosia, który wszedł do bagna", $[\ldots]$ to się przeraziłem. Toż to jak wyciąganie ryby z wody. Panie Premierze, toć łoś żyje na bagnach. I on je uwielbia i kocha. Bo łoś, Panie Premierze, to zwierzę bagienne, co potrafi znakomicie pływać, jak chce, to i nurkować [...] Dlatego nie wyciągajcie łosia z bagien. Niech sobie na nich mieszka („Gazeta Wyborcza"; 14 IX 2007).

Translation: Mr Premier, I've read the interview with you in 'Rzeczpospolita' and I froze [...] when I read that 'pushing Poland forward is like dragging an elk out of the marshes', it terrified me. It's like pulling fish out of water. Mr Premier, the elk lives in the marshes. The elk loves and enjoys them. Because the elk, Mr Premier, is a marshy animal that can nicely swim, or, if it wants, dive. [...] This is why, please, don't drag the elk out of the marshes. Let it live there.

Two metaphors were used in this text: pushing Poland forward and dragging out an elk which went into the marshes. Both metaphors realize Type III, as they present the politician's point of view which is ironically and critically put in the journalist's commentary.

The above example reveals that the difference in secondary nomination is founded on the difference of the designate interpretation; hence, the interactional metaphor reflects the intercultural relations: the metaphorical polyphony equates the confrontation or even contrast of cultural points of view, in other words of the cognitive competences. The highest degree of intercultural difference can be observed in metaphorical expressions of Type III: here an essential competition occurs between contrasting points of view, with the aid of expressive or evaluative modality. Metaphorical expressions of Type I are more neutral in this respect.

The following press text can serve here as an example of the foreign nomination being inserted into the 'my text':

(13) Dziurki informacji (tytuł). Badacze z Kalifornii twierdzą że dzięki dwóm otworom nosowym mózg otrzymuje pełniejszą informację o zapachach. Powietrze przepływa przez jedną dziurkę szybciej niż przez drugą ze względu na lekkie opuchnięcie jednej strony nosa. Co kilka godzin następuje zmiana. Wielkość opuchlizny wpływa na szybkość wdychania aromatów i wchłaniania ich przez błonę śluzową. Zdaniem Noama Sobela ze Stanford University, otwory nosa inaczej czują zapachy [...] Dwudziestu ochotników wąchało substancję, która wydzielała zapachy wchłaniane i szybko, i wolno (po połowie). Badania potwierdziły wcześniejsze przypuszczenia, że każda dziurka „postrzega” świat inaczej („Wprost”; 1999/49).

Translation: The holes of information (the title). Californian scientists maintain that through nostrils the mind receives a complete information about scents. The air passes quicker through one hole than through the other as a consequence of one nostril being a little swollen. Every few hours a change takes place. The degree of nostril swelling affects the speed of fragrance inhaling and its absorption through the mucosa. According to Noam Sobel from Stanford University, nostrils process fragrances differently [...]. Twenty volunteers were smelling a substance, which was producing the odors absorbed quickly or slowly (half and half). The research confirmed the initial hypothesis that each hole 'perceives' the world differently.

The invariant content was expressed twofold: from the point of view of the physiologist Noam Sobel, with whom the text the author identifies himself/herself; and from the point of view of a psychologist, who uses a different type of nomination (the inverted commas reflect it).

'Sobel, a scholar and physiologist, says that nostrils smell smells differently; a person who busies himself/ herself with psychology (that is, another, in a sense foreign, scientific discipline) could say that each hole perceives the world differently'. 
Another case is composed of metaphorical expressions in which the subject of metaphorical nomination is a speaker or a group with which he is identified, and the linguistic contrast results from the confrontation of 'my word' and the 'neutral word'. This situation is visible in the following sentence:

(14) Zaprosił mnie na próbę. Nie mam pojęcia, jaka siła mnie popchnęła, bo strasznie się wstydziła wszystkiego i wszystkich. Ale coś zaśpiewałam „p o n o r w e s k u” (wymyśloną angielszczyzną) („,Wysokie Obcasy"; 2002/15).

Translation: He invited me to the audition. I have no idea which force pushed me as I was ashamed to death of everything and everybody. But I sang something 'in Norwegian' (fake English).

Here an element of socially-marked style was introduced into the text written in the neutral convention. The metaphorical description in Norwegian indicates the process of the incorporation of 'my word' into the 'neutral word'.

'I sang in fake English; in the musicians' circle where I belong it is described as singing in Norwegian'.

The intercultural relations which are coded in metaphorical expressions characterize publications of social and political journalism, which can be observed in Anna Łabuszewska's texts (see example 1). I will demonstrate the realization of selected metaphorical interaction types on the example of another journalistic text - the publication by Bartłomiej Sienkiewicz, entitled Wojna w Europie (War in Europe), printed in 'Tygodnik Powszechny' (2009/32). The central question of the text is whether there are ideological premises for a war in Europe today. At the outset, the author refers to the European experts' standpoint, at the same time delineating the scope of interpretative references - the source of the metaphorical nominations:

(15) W setkach przemówień polityków europejskich przewija się wciąż ten sam motyw: Europa jest kontynentem bez wojen. Wojna jako potencjalna część przyszłości została z Europy egzorcyzmowana raz na zawsze.

Translation: 'In hundreds of European political speeches the same motif reappears continuously: Europe as the continent without wars. War as a future potential has been exorcised for good'.

Indeed, in the text, most frequent are metaphorical expressions which are either citations from speeches of European politicians, from texts by political science experts, or from media texts. Semi-quotations, which resemble regular citations, are episodic, for example:

(16) Piewcy Europy jako swoistej szklarni (,,kry s ztałowe go pałacu”, jak chce Peter S lot e r d i j k), w której spełniły się marzenia ludzkości o wiecznym szczęściu, po w oł u ją s i ę c zę s to n a „p o s th e r o i c z n o ś ć” jako stały składnik europejskiej samoświadomości.

Translation: Glorifying voices of Europe being a specific greenhouse ('the Crystal Palace', as Peter Sloterdijk wants to call it), in which all dreams the humankind had about everlasting happiness, came true, refer often to 'the postheroism' as a constant component of the European self-consciousness.

In most cases, however, one comes across a linguistic phenomenon that can be described as a metaphorical citation, that is, phrases which come from a virtual, non-specified subject, and which express an opinion that is agreed upon in the political-medial circles. The opinion cannot be estimated to be foreign to the real sender; however, a certain distance the sender adopts towards the secondary nomination is well-visible. This is reflected in the general explication of expressions of a this type:

'Somebody (from the political-medial world) says/would say that P.

I wouldn't say so.

I intend to point to what a person from a political-medial world would say'. 
A variety of metaphorical expressions in press texts contributes to their pluralistic tone, the reflexive semantic lay-out, and the hidden intercultural dialogue; in addition, there are alternative points of view included in such texts; for example, in Sienkiewicz's text:

(17) W pewnym momencie właściwie każda mocna identyfikacja narodowa może stawać się rodzajem „współczesnego faszyzmu”.

Translation: A moment comes when, actually, any form of nationalism can become a form of 'modern fascism'.

(18) Zwolennicy Europy jako obszaru politycznego, któremu udała się „u c iec zka od his tori i”, wymieniają także dwa inne argumenty.

Translation: Advocates of Europe as a political area which managed 'to escape from history', put forth also two other arguments.

(19) Straty mogą się okazać nie do odrobienia, a osunięcie się całego regionu do poziomu „n i e stabil nych terytoriów" dodatkowo go osłabi.

Translation: The loses may not to be undone, and the descent of the region to the level of "non-stable territory' will weaken it even further.

In expressions of this type, the official, expert voice is activated - as a result, the expressive tone of such texts is moderate. Stylistically these texts refer to high register.

The metaphor 'frozen conflict' may be treated here as an exception, as found in the following context:

(20) Osobnym problemem jest Rosja — największy „, z a m ro ż o n y k o n fl i k t” w Europie. Cała polityka wewnętrzna i zagraniczna tego państwa (Rosji - A. K.) jest demonstracją niezgody na przejście od roli supermocarstwa do mocarstwa regionalnego (elementem tego pierwszego była także kontrola nad Europą Środkowo-Wschodnią). Ów resentyment jest ciągle podsycany przez władzę jako osłona własnej nieudolności autorytatywnych rządów.

Translation: Russia is a separate problem — the biggest 'frozen conflict' in Europe. Its (Russian) internal and external policy constitutes a demonstration of the disagreement to the transformation from a superpower to a regional power (the former included also the control over Central and Eastern European satellite countries). This sentiment is being continually amplified by the authorities, being veil for hiding the lack of functional effectiveness of authoritative rule.

One can assume that the metaphorical expression 'frozen conflict' presents the expert perspective, which stands in opposition to both the author's opinion, and the opinion of the supposed 'foreigner' - the official representative of the Russian government. On the one hand, there is the author's evident inclination to erase the adjective frozen from the expression frozen conflict, as he seems to perceive the situation in Russia being too tense and nonstable and creating the potential of a new war in Europe. On the other hand, in the assumed Russian perspective, the noun conflict is inappropriate, which is visible in the pragmatic analysis presented below:

Voice A (the real sender): The political situation in Russia is very tense, creating a potential for a military conflict.

Voice B (the virtual sender): An expert of political science or a media representative would say about it: the frozen conflict.

[Voice A: I wouldn't say: the frozen conflict, but the real conflict, the real threat to the European security].

[Voice C: The official representative of the Russian government wouldn't say: the frozen conflict, but a regular, government-controlled political-economic situation].

Apart from metaphorical expressions in which the neutral, expert point of view is exhibited, the text discussed here contains expressions of a different type, which profile the endo- 
centric subject, that is the person speaking. Metaphors of this type contain more evaluating semantics, namely, categorical judgments, and are more expressive.

The author uses his own secondary nominations, and in this way his perception is juxtaposed with the cool rationalism of the experts. In addition, contrary to expert metaphors, the author's metaphors are rather colloquial in character, which can be noticed in the following examples:

(21) Do tego dochodzi zakażenie państwowości rosyjskiej przemocą i pogardą dla prawa - cena, jaką płaci ten kraj za panowanie nad Czeczenią i Kaukazem. Stąd pełne napięć i konfliktów relacje Rosji z sąsiadami.

Translation: Apart from this, there is the Russian national profile infected with contempt and violence for law - the price this country pays for the domination over Chechnya and Caucasus. This is the source of the tense and conflicted relations of Russia and its neighbors.

(22) Zachodni błąd poznawczy prowadzi do akceptacji najdziks zy ch w y b y ków państwowoś c i ro s y j k i ej, z nadzieją, że jedynym skutecznym lekarstwem są cierpliwość i wyrozumiałość.

Translation: A cognitive error of the West leads to the acceptance of the most wild extravagances of the Russian statehood, hoping that it is patience and leniency that constitute the only effective medicine.

(23) E rozji u lega ją wszystkie elementy strategiczne bezpieczeństwa europejskiego. Translation: All strategic components of the European security are subject to erosion.

(24) Ten tekst powstał z okazji pierwszej rocznicy wybuchu wojny w Gruzji. W jej efekcie Gruzja przestała się liczyć na arenie międzynarodowej jako kandydat do Sojuszu, a dalej - do świata Zachodu. ,Z m i e n i ł a li g ę" na niższą. [...]

Translation: This text was written on the occasion of the first anniversary of the war in Georgia. As a result of the war, Georgia lost her position on the international arena as the candidate for NATO membership; and further, as the candidate for the member of the West. Georgia has passed to a lower league. [...]

The above presented and similar metaphorical expressions can be ascribed to a general model:

Voice A (the real sender): I talk about it.

Voice A (the virtual sender): I would say something else about it (for instance, following somebody else's opinion); I would say that $P$.

[Voice B: The majority would not say / experts would not say that P].

[possibly: Voice C: The foreigner would not say about it that P].

\section{CONCLUSION}

In conclusion, it is worth emphasizing that metaphor does not only belong to tropes, that is, to decorative textual tools, described in rhetoric and in poetics as the feature of the artistic style; apart from this, metaphor is a vital aspect of the semantic organization of the text, namely, in profiling certain intercultural relations. Such a view on metaphor seems especially useful in analyses of press publications, especially texts on international affairs, as in this case metaphorical expressions have the ideological content and express attitudes.

'After Dostoyevsky all we can do is to play with metaphors' said J. P. Sartre. The present study depicts a model of metaphor in language communication, in which pragmatic transcoding allows for viewing a metaphor as a process of 'giving somebody the floor'; as a result, the sender can select the intended interpretation of the depicted events and states of affairs. The choice of 'voice' allows for the most adequate content presentation - as far as 
the sender's intention is regarded; in addition, it becomes possible - from the sender's point of view - to effectively affect the addressee.

\section{REFERENCES}

Bachtin Mikhail М. [Бахтин Михаил М.]. 1979. Эстетика словесного творчества. Москва: Искусство. BogusŁawski Andrzej. 1994. Sprawy stowa. Word Matters. Warszawa: Veda.

KarolaK Stanisław. 1999. “Kondensacja (ściągnięcie).” In: PolańSKi 1999: 307-309.

KiKLEwicz Aleksander. 2006. "Dyfuzja semantyczna w języku i w tekście II.” LingVaria 2, 9-20.

KIKLEWICZ Aleksander. 2009a. "Funkcjonalno-komunikacyjne aspekty teorii metafory." Poradnik Językowy 3, 53-67.

KIKLEWICZ Aleksander. 2009b. "Pragmatyczne aspekty kodowania informacji w języku II.” Prace Filologiczne LIV, 167-184.

LAZARI Andrzej de. 2007. “Jerzego Giedrojcia ‘wołanie na puszczy’.” Przeglad Humanistyczny LI(5), 1-5.

Ortony Andrew (ed.). 1979. Metaphor and Thought. London-New York-Melbourne: Cambridge University Press.

Pelinko Marta. 2005. Humor zeszytów szkolnych. Warszawa-Rzeszów: Ad Oculos.

PolaŃsKI Kazimierz (ed.). 1999. Encyklopedia językoznawstwa ogólnego. Wrocław-Warszawa-Kraków: Zakład Narodowy im. Ossolińskich.

Richards Ivor Armstrong. 1936. The Philosophy of Rhetoric. Oxford: Oxford University Press.

Searle John Rogers. 1979. "Metaphor.” In: Ortony 1979: 92-123.

SpagiŃSKa-PruszaK Agnieszka. 2005. Intelekt we frazeologii polskiej, rosyjskiej, chorwackiej. Lask: Leksem.

Ullmann Stephen. 1967. Grundzüge der Semantik. Die Bedeutung in sprachwissenschaftlicher Sicht. BerlinNew York: De Gruyter.

Vološınov Valentin N. [Волошинов Валентин Н.]. 1995. Философия и соииология гуманитарных наук. Санкт-Петербург: Аста-Пресс LTD. 